\title{
Relationship Between PPKN Subjects and Increasing the Spirit of Nationalism of Indonesian Students in Saudi Arabia
}

\author{
A Masrukhin $^{1 *}, \mathrm{H} \mathrm{Sriyanto}^{2}$ and M N Willyarto ${ }^{3}$ \\ ${ }^{1}$ Agus Masrukhin, Character Building Development Center, Information Systems Department, School of Information Systems, \\ Bina Nusantara University, Jakarta, Indonesia 11480 \\ ${ }^{2}$ Hari Sriyanto, Character Building Development Center, Industrial Engineering Department, Faculty of Engineering, Bina \\ Nusantara University, Jakarta, Indonesia 11480 \\ ${ }^{3}$ Language Center, Industrial Engineering Department, Faculty of Humanities, Bina Nusantara University, Jakarta, \\ Indonesia 11480. Research Interest Group Cross-Cultural Communication \\ Banten 15143 \\ *Corresponding author email: agus@binus.ac.id
}

\begin{abstract}
This study aimed to obtain an overview of the relationship between Civics subjects with the spirit of nationalism of Indonesian students. This study used a qualitative and quantitative approach with the correlation study method. The research data were obtained through questionnaires and tests given to 122 students at Jeddah Indonesian School (SIJ). Data analysis used model correlation SPSS 16.0. The results of the study revealed that, the implementation of civic education as a general basic subject included in the subject of personality development has been carried out well, students have a strong sense of nationalism, the application of Civics as a general basic course had a major correlation and effect on increasing the nationalism and nationalism spirit of Indonesian students in Jeddah Indonesian School (SIJ).
\end{abstract}

Keywords: PPKN, Spirit Nationalism, Saudi Arabia

\section{INTRODUCTION}

we have known that in this era a lot of young generation tends to forget and choose to become competitive individuals and then ignore their nationality[1], then this is a heavy task for teachers in education the young generation. In the positive law, article 37 paragraph [2] of Law No.20 of 2003 concerning the National Education System states that "Citizenship Education is intended to shape students into human beings who have a sense of nationality and love the country". However, to obtain these results was certainly not easy, there were many factors that affect it consisting of three stages. First is the input. This was related to PPKn material, teachers, school environment, family environment and learning methods and facilities. Second was the process, related to the teacher teaching method and classroom management by the teacher. The third was the output, the expected result, namely having the spirit of nationalism.

The fading of Pancasila values indirectly raised the problem of nationalism in Indonesia. The last few years had become a concern for the government and citizens who care about the existence of the unitary state of the Republic of Indonesia. Kartodirjo assessed that the nationalist ethos of the political elites in Indonesia had diminished, therefore Kartodirjo appealed to the political elite to immediately introspect themselves by reviewing the history of the national movement through biographies of national movement figures [3]. This concern is also shared by educators who state that some of Indonesia's younger generations are currently experiencing an erosion of nationalism. such as the attitude of some of the younger generation who do not really appreciate national symbols, such as the nationalism song (Indonesia Raya), fundamental symbols such as the Red and White flag and the slogan of Nationalism Bhineka Tunggal Ika [4].

For the sake of the sustainability of the country, it is good when the younger generations have nationalist character values that are reflected in attitudes, thoughts and actions, showing loyalty, concern, and high respect for the nation's language, socio-culture, economy and politics, and placing the interests of the nation and state above self-interest. and his group. A nationalist attitude and spirit are needed to support national resilience, the constituent elements of language, religion, ethnicity and culture. The elements forming national resilience will not exist if the younger generations do not have a 
nationalist attitude, especially in the globalization era where science and technology are developing rapidly in the midst of society. According to Anthony Giddens, the definition of globalization is the intensification of social relations globally so that it connects events in one location to another and causes changes in both[5].

So it is necessary to have the Strengthening Character Education (PPK) which is a process of forming, transforming, transmitting and developing the potential of students to think well, have good hearts, and behave well in accordance with the Pancasila philosophy of life. The principles used include: 1 . universal values; 2 . holistic; 3 . integrated; 4 participatory; 5. local wisdom; 6. 21st century prowess; 7. fair and inclusive; 8 . in line with the development of students; and 9 measurable. The form of activities of Strengthening Character Education that can be carried out: (i) intra-curricular activities, activities carried out by schools on a regular and scheduled basis; (ii) co-curricular, supporting activities from intra-curricular; (iii) extra-curricular, activities that are carried out outside of regular learning hours[6]. However, there is no guarantee that education with a clear curriculum will produce tolerant and open students, if we pay attention to the research of Sriyanto and Masrukhin which was published in the IOP journal publication that the main factor of learning is not the material and methods of the teacher but the students [7]. Another in the research conducted by Sofyan and Sundawa[8], it was found that there was a strong correlation between PPKn and the spirit of nationalism and it had a great influence. This is the benchmark and comparison of this study to reveal the relationship between the two variables with different objects.

Sofyan and Dadang's research results prove the correlation of the two parties. that the conditions for the application of the civic education course as a general basic course, the conditions for understanding the national insight and the spirit of students in the Garut Teaching and Education College are in good categories with predetermined classifications [9]. Putri and Yuli's research[10] shows that the increase in the values of nationalism is cognitive, meaning that from previous research that the school's efforts in learning citizenship to its students have different results. This can support this research. Either to improve or complement the previous findings.

This research is entitled: Relationship between PPKn Subjects and Increasing the Spirit of Nationalism of Indonesian Students in Saudi Arabia.
This research was using a case study approach, with SPSS 16.0 analysis with the aim of describing the relationship between PPKn lessons and the spirit of nationalism and to determine the closeness of the relationship between the two variables. There are many influencing factors in the relationship between PPKn subjects and the spirit of nationalism. Based on the background description of the problem, it is important to examine the correlation between the Citizenship Education course and the increase in the spirit of nationalism of students in the Jeddah Indonesian School (SIJ). From the formulation of these problems, the research questions are further detailed as follows: 1) How is the description of the student response to the Citizenship Education (PPKn) lesson which is held at the Indonesian School, Jeddah Saudi Arabia? 2) How is the correlation and level of correlation between the variables of PPKn lessons with the spirit of nationalism of the students?

\section{METHOD}

This study uses qualitative and quantitative methods, while the research subjects are Indonesian students who are studying at the Jeddah Indonesian School (SIJ). This study also uses cases study research about correlation the PPKn subject with Nationalism soul. To reveal the research problem, the author used analysis Kendal's theory, PPKn education curriculum and Nationalism e concepts. This study uses primary data sources and secondary data. According to Saifuddin [11] that primary data obtained from research subjects in this case were the results of interviews with school residents in Saudi Arabia. According to Sugiyono [12] that primary data sources are data that directly provide data to data collectors, this is Sekolah Indonesia Jeddah (SIJ). While secondary data come from outside the main sources such as books, articles, documents and manuscripts. Garraghan said [13] The final stage is the art of writing, especially in research analysis that uses theories and social science concepts to understand social facts. There were 112 respondents from SIJ and 4 teachers and 6 students as resource persons. The main data source is the person interviewed directly. Among the informants and respondents who will be used as research partners are teachers, school students and school principals. The validity of the data is done in order to obtain valid results and can be scientifically justified. The validity of the data in qualitative research is a systematic examination effort in accordance with certain procedures in skin research consistently. 


\section{RESULT DISCUSSION}

Sudjana and Ibrahim [14] explain the meaning of the correlational research method, "correlation studies study the relationship between two or more variables, namely the extent to which variations in one variable are related to variations in other variables."

\section{Variable X (PPKn Subject)}

- PKN subject matter in schools is easy to understand

Discussing what students felt related to PPKn lessons, it turned out that $42 \%$ of the 112 students stated that they did not agree that if the PPKN subject was easy to understand, they answered neutral. This indicates that there is an indication that the KDPn lesson material is ineffective or that the teaching methods may not be appropriate. This has an impact also on the consistency of the correlation between PPKn lessons and nationalism.

- Items on the Evaluation of Civics lessons are very important as a way to find out an understanding of citizenship. From the results of the analysis of the calculation of the questionnaire and SPSS tables, it appears that 40 students stated that they were neutral and did not agree with the evaluation of PPKn lessons, of course this would be homework for schools to find out the reasons that consider the evaluation of PPKn lessons as the basis for students' knowledge about understanding citizenship is not important.

- Learning activities in Civics subjects are quite interesting and not boring, as many as 34 students are neutral, meaning they are less interested in PPKn lessons and 6 people clearly state that they are not interested in PPKN lessons

- I am quite enthusiastic about participating in the Civics Education (PKN) subject at school. Based on the research table, 37 students answered neutral and were not enthusiastic about learning PPKN
- The values of the Citizenship Education (PKN) subject affect me in my daily life. 83 students agreed that PPKn was influencing

- $\quad$ The PKN subject adds to my understanding of love for the country. 105 students feel that the PPKN lessons add to the love of the country. This is a pretty good result but it doesn't seem like a straight line to the results of the previous item. If they are up to $80 \%$ happy, they enthusiastically participate in PPKn lessons

Variable Y (Nationalism Soul)

- Proud to be an Indonesian with cultural diversity

- I am sad if there are conflicts between religions and tribes in Indonesia

- I love Indonesian products

- Enjoy working together with friends of different ethnicities, religions, and groups in doing school work

- Difference is a gift from God, so I am not impartial in making friends

As a basic and main requirement in research based on a quantitative approach, data validity is data reliability. This is very important in order to support the results of data analysis in the hope that it will approach the truth. Therefore, the researcher uses several variable items which are considered to be able to explain the source of the research problems. Variable X consists of six (6) questions and variable $\mathrm{Y}$ consists of five (5) questions. Respondents who helped fill out the questionnaire were 112 Indonesian students and schoolteachers. Descriptively they answered well, although there were also those who answered not according to the instructions for the questions. Based on the validity and reliability test, it shows that the items of the research variables are all valid. That is, overall, the calculated $r$ value is greater than the $r$ table value, namely the smallest is $0.551>$ greater than 0.195 . Likewise, the reliability test, based on the reliability output table, the Guttman Split correlation value is $0.831>0.80$. Thus, the items of research variable were competent. 
TABLE 1. Cronbach's Alpha

\begin{tabular}{|l|r|r|r|r|}
\hline \multicolumn{5}{|c|}{ Item-Total Statistics } \\
\hline & $\begin{array}{c}\text { Scale Mean if Item } \\
\text { Deleted }\end{array}$ & $\begin{array}{c}\text { Scale Variance } \\
\text { if Item Deleted }\end{array}$ & $\begin{array}{c}\text { Corrected Item-Total } \\
\text { Correlation }\end{array}$ & $\begin{array}{c}\text { Cronbach's Alpha if } \\
\text { Item Deleted }\end{array}$ \\
\hline IP1 & 10.04 & 7.278 & .563 & .807 \\
\hline IP2 & 10.53 & 7.423 & .580 & .804 \\
\hline IP3 & 10.11 & 6.367 & .638 & .794 \\
\hline IP4 & 10.10 & 6.720 & .665 & .785 \\
\hline IP5 & 10.23 & 7.153 & .606 & .799 \\
\hline IP6 & 10.74 & 7.671 & .551 & .810 \\
\hline
\end{tabular}

TABLE 1. Correlation

\begin{tabular}{|c|c|c|c|c|}
\hline \multicolumn{5}{|c|}{ Correlations } \\
\hline & & & PPKn & Nasionalisne \\
\hline \multirow[t]{6}{*}{ Kendall's tau_b } & \multirow[t]{3}{*}{ PPKn } & $\begin{array}{l}\text { Correlation } \\
\text { Coefficient }\end{array}$ & 1.000 & $.293^{* *}$ \\
\hline & & Sig. (2-tailed) & & .000 \\
\hline & & $\mathrm{N}$ & 112 & 112 \\
\hline & \multirow[t]{3}{*}{ Nationalism } & $\begin{array}{l}\text { Correlation } \\
\text { Coefficient }\end{array}$ & $.293^{* *}$ & 1.000 \\
\hline & & Sig. (2-tailed) & .000 & \\
\hline & & $\mathrm{N}$ & 112 & 112 \\
\hline
\end{tabular}

Based on the SPPS test using Kendall's correlation test, seeing the relationship with the significance value, it is known that the significance value between the PPKn lesson variables and nationalism is 0.000 smaller than 0.05 . Therefore, it can be concluded that there is a significant relationship between PPKN and nationalism. The correlation coefficient value is sufficient, which is 0.293 , based on the guidance from Jonathan Sarwono.

\section{CONCLUSION}

Based on the formulation of the problem, the researcher concluded that there was a significant relationship between PPKN lessons and the spirit of nationalism. The value of the correlation coefficient is sufficient, which is 0.293 , this is known from the significance value between the PPKn learning variables and nationalism is 0.000 , smaller than 0.05 . Even so, school students feel the benefits of PPKn learning. From the construction of PPKn learning, it is necessary to evaluate because it was found from the results of the analysis table with the SPSS program, that quite a lot of students from SIJ schools were not interested in PPKn lessons even some of them were not enthusiastic about receiving PPK lessons.

\section{ACKNOWLEDGMENTS}

"This work is supported by Research and Technology Transfer Office, Bina Nusantara University as a part of Bina Nusantara University's International Research Grant entitled Relationship between PPKn Subjects and Increasing the Spirit of Nationalism of Indonesian Students in Saudi Arabia with contract number: No.026/VR.RTT/IV/2020 and contract date: 6 April 2020.”. 


\section{REFERENCES}

[1] M. Z. Alfaqi, "Melihat Sejarah Nationalism e Indonesia ," J. Civ., 2016.

[2] UU Republik Indonesia No.20, Tentang Sistem Pendidikan Nasional. Indonesia: Kementrian Pendidikan dan Kebudayaan Republik Indonesia, 2003.

[3] Kartodijo, "Biografi Tokoh Nasional," Kompas, 2001.

[4] Prabowo, "Terjadi Erosi Nationalism e Kaum Muda," Kompas, 1995.

[5] P. Setiawan, "Pengertian Dan Dampak Globalisasi Menurut Para Ahli," https://www.gurupendidikan.co.id/, 2020.

https://www.gurupendidikan.co.id/pen gertian-globalisasi/ (accessed Dec. 17, 2020).

[6] Kementerian Pendidikan dan Budaya, Konsep dan pedoman penguatan pendidikan karakter. Jakarta: Tim PPK Kemendikbud, 2016.

[7] H. Sriyanto and A. Masrukhin, "The role of module quality, learning methods, and lecturers with student learning outcomes: Model multiple regression \{SPSS \} approach,” J. Phys. Conf. Ser., vol. 1402, p. 22066, Dec. 2019, doi: 10.1088/1742-6596/1402/2/022066.

[8] F. S. Sofyan and D. Sundawa, "Hubungan Mata Kuliah Pendidikan Kewarganegaraan Dengan Peningkatan Wawasan Kebangsaan Dan Semangat Nationalism e Mahasiswa," J. Pendidik. ILMU Sos., 2016, doi: 10.17509/jpis.v24i2.1455.

[9] F. S. \& D. S. Sofyan, "Hubungan Mata Kuliah Pendidikan Kewarganegaraan Dengan Peningkatan Wawasan Kebangsaan Dan Semangat Nationalism e Mahasiswa," JPIS, J. Pendidik. Ilmu Sos., vol. 24, no. 2, 2015.

[10] N. A. Putri, Y. Kurniawati, and S. Pranoto, "The Implementation of Storytelling Method for History Education to Develop Nationalism Attitudes of Early Childhood in Handayani Brebes Kindergarten," Belia Early Child. Educ. Pap., vol. 6, no. 2, pp. 68-73, 2017.

[11] Saifuddin, Metode Penelitian. Yogjakarta: pustaka Pelajar, 1997.

[12] Sugiono, Research Methods, Quantitative, Qualitative, and R\&D. Bandung: Alfa Beta, 2017.
[13] W. Hernawan, "Islamic unity:background and development. dissertation," p. 3, 2018.

[14] N. dan I. Sudjana, Penelitian dan Penilaian Pendidikan. Bandung: Sinar Baru Algesindo, 2007. 